\title{
Comparison of Geotechnical Properties of Laterite, Kaolin And Peat
}

\author{
S. A. N. Mohd Yusoff ${ }^{1, a}$, I. Bakar ${ }^{1 * 2, b}$ D.C. Wijeyesekera ${ }^{1 * 2, c}$ \\ A. Zainorabidin ${ }^{1 * 2, d}$, A. Madun ${ }^{1 * 2, e}$ \\ ${ }^{1}$ Research Centre for Soft Soil / Universiti Tun Hussein Onn Malaysia / Batu Pahat, Johor Malaysia \\ ${ }^{2}$ Department of Infrastructure \& Geomatic Engineering / Universiti Tun Hussein Onn Malaysia \\ /Batu Pahat, Johor Malaysia

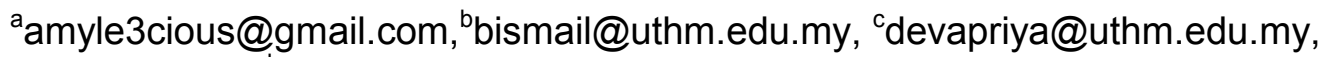

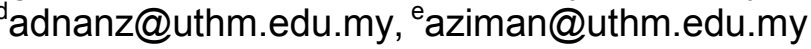

Keywords: Laterite, Kaolin, Peat, Basic properties test, Standard Proctor Test, Unconfined Compressive Strength and California Bearing Ratio

\begin{abstract}
Geotechnical properties are influenced by the different types of soil. The objective of this study was to investigate the behaviour of geotechnical properties on different types of soil. This paper compares some geotechnical properties of Kaolin, Laterite and Peat. Laterite was collected from Bukit Banang while Peat sample was collected from Parit Nipah, both locations were in Batu Pahat, Johor. Meanwhile, kaolin that was used in this research was manufactured kaolin. A laboratory testing program consists of basic properties tests were conducted in order to obtain general information on the materials (e.g Natural moisture content, Atterberg Limit, Specific gravity, grain size analysis, chemical composition and $\mathrm{pH}$ ). Further tests have been carried out in determining the geotechnical properties of the soil which evaluates its behaviour for design and construction suitability. The results showed that the Natural/initial moisture content for, peat is higher than laterite and kaolin. Meanwhile Specific gravity for Peat is the lowest among kaolin and laterite. It was also found that the $\mathrm{pH}$ of all soil is acidic which lay in the range of 3.76-5.95. The UCS and CBR is compacted in same energy and been tested. This paper summarizes the result of analysis performed on all tests conducted. From the study it can be summarized that geotechnical properties of a soil is highly depending on its type.
\end{abstract}

\section{Introduction}

Geotechnical engineering is a speciality of Civil Engineering which deals with the properties, behaviour and use of earth materials (soil and rocks) in engineering works [1]. In most geotechnical engineering projects and problems, site characterization and property evaluation are the two most important elements. Thus, running through every aspect of the work is the need for sufficient understanding of what soils are and the principles that govern their importance. Soils are naturally occurring, highly complex materials with variable ingredients and properties. Since there are so many types of soils, it is important to describe and classify them in terms that exude their characteristics clearly and concisely [2].

A lot of studies have been done by previous researchers to find out more about the different of physical and engineering behaviour of different types soils. Particle size analysis is important for characterizing a variety of physical properties and affect porosity and permeability, and they are also related to the geotechnical properties of sediment [3]. Determination of soil conditions is the most important in civil engineering works. The geotechnical properties of soil such as its grain-size distribution, plasticity, compressibility, and shear strength can be assessed by proper laboratory testing [4]. This paper discusses the comparisons of geotechnical properties of compacted laterite, kaolin and peat.

\section{Materials and Methods of Testing}

Natural sample of Laterite (obtained from Bukit Banang, Batu Pahat) and Peat (obtained from Parit Nipah, Batu Pahat) was obtained manually from a borrow pit at a depth of about $1.5 \mathrm{~m}$. The kaolin used in this research is manufactured Kaolin from the K\&M Kaolin Malaysia Sdn Bhd. The 
collected and manufactured soil was subjected to laboratory tests in order to determine its basic and geotechnical properties. The test conducted included Natural Moisture Content, Atterberg Limits, Particle Size Analysis, Compaction (Standard proctor test), Unconfined Compressive Strength test (UCS) and California Bearing Ratio (CBR). These tests were conducted based on B.S 1377-1990.

\section{Results and Discussions}

Soil properties Soil classification test were perform based on BS 1377 (1990). The detailed results were summarized in Table 1 below.

Table 1 Index, chemical and mineralogical properties of studied soils

\begin{tabular}{clccc}
\hline Parameter & \multicolumn{1}{c}{ Sample } & Laterite & Kaolin & Peat \\
\hline Moisture Content & Natural Moisture Content & 22.54 & 0.22 & 480.61 \\
Particle Size & Gravel (\%) & 6.690 & - & - \\
Distribution & Sand (\%) & 32.512 & - & - \\
& Clay (\%) & 49.003 & 12.35 & - \\
& Silt (\%) & 11.796 & 87.67 & 47.465 \\
& $\mathrm{D}_{10}(\mathrm{~mm})$ & 0.0019 & 0.0014 & 0.0065 \\
& $\mathrm{D}_{30}(\mathrm{~mm})$ & 0.0090 & 0.0040 & 0.016 \\
& $\mathrm{D}_{60}(\mathrm{~mm})$ & 0.2 & 0.0086 & 0.5 \\
& Cu & 105.26 & 6.143 & 76.92 \\
& Cc & 0.213 & 1.329 & 0.0787 \\
Consistency & Liquid Limit (\%) & 54 & 71 & 162.11 \\
Limits & Plastic Limit (\%) & 23.1 & 37.43 & - \\
& Plasticity Index (\%) & 30.9 & 33.57 & 162.11 \\
Classification & AASHTO & $\mathrm{A}-7-6$ & $\mathrm{~A}-7-5$ & $\mathrm{~A}-8$ \\
& USCS & $\mathrm{CL}$ & $\mathrm{CH}$ & Peat,Pt \\
Particle Density & Specific gravity & 2.79 & 2.47 & 1.43 \\
Acidity of soil & pH & 5.95 & 5.54 & 3.76 \\
& LOI (\%) & 21.83 & 14.22 & 92.7 \\
\hline
\end{tabular}

Table 1 indicated that Coefficient of uniformity $(\mathrm{Cu})$ for laterite, kaolin and peat is $105.26,6.143$ and 76.92 while coefficient of curvature $(\mathrm{Cc})$ is $0.213,1.329$ and 0.0787 respectively. Meanwhile, the Plasticity index for investigated soil is 30.9\% (laterite), $33.57 \%$ (kaolin) and $162.115 \%$ (peat). By using USCS classification, laterite was classified as CL, both kaolin and Parit Nipah peat was classified as $\mathrm{CH}$ and $\mathrm{Pt}$. All of the investigated soil is characterize as acidic and peat has the higher amount of organic content than laterite and kaolin.

Compaction Test The compaction curve presented in Fig.1 and Fig.2 was determined using the standard Proctor method. The value of maximum dry densities (MDD) and optimum moisture contents (OMC) for the soils has been summarized in Table 2. Moisture Density relationship Standard proctor tests were carried out on Laterite, Kaolin and Parit Nipah Peat.

Table 2 Summarize of standard proctor test result

\begin{tabular}{cccc}
\hline Compaction Parameter & Kaolin & Laterite & Parit Nipah Peat \\
\hline Maximum dry density, MDD $\left(\mathrm{Mg} / \mathrm{m}^{3}\right)$ & 1.410 & 1.630 & 0.490 \\
Optimum Moisture Content, OMC $(\%)$ & 27 & 22.5 & 132.47 \\
\hline
\end{tabular}




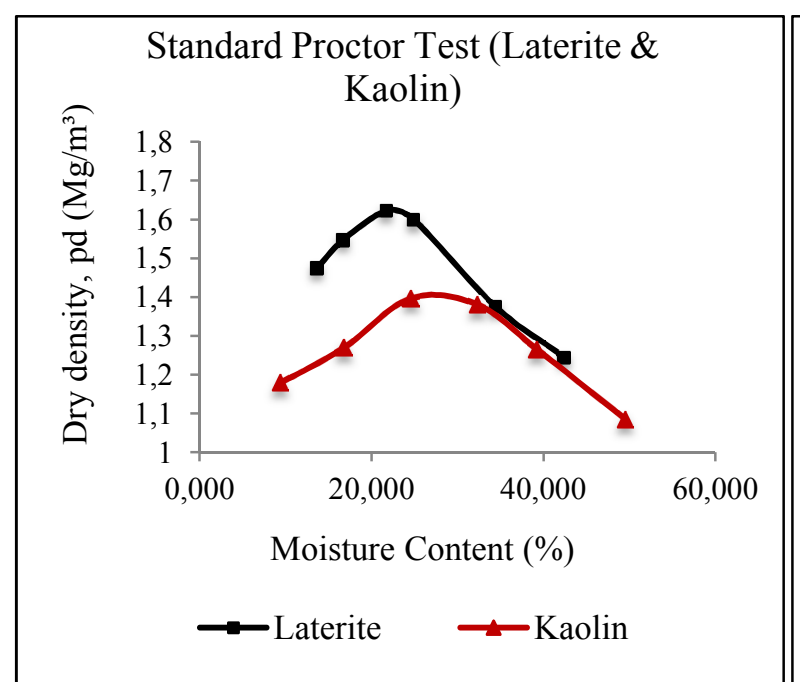

Fig. 1 Compaction curves for Laterite and Kaolin

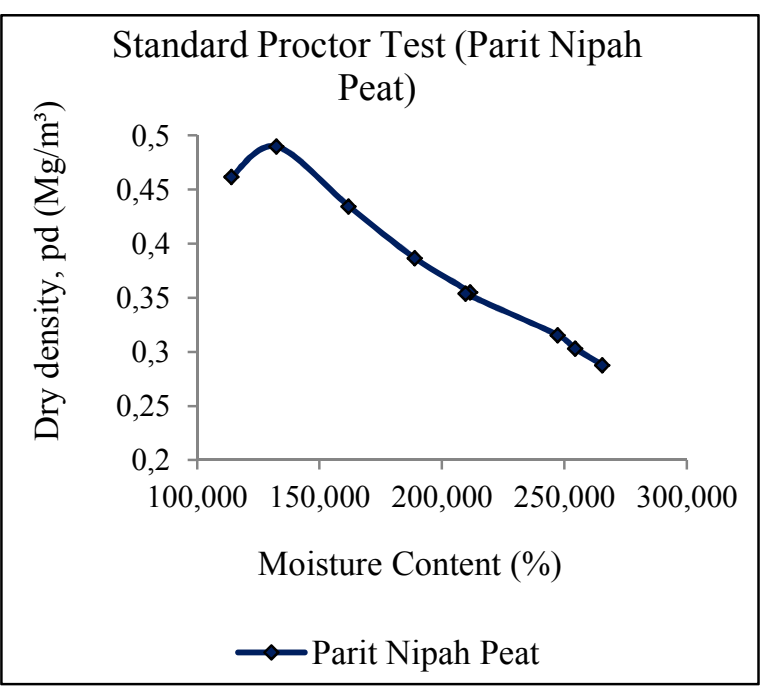

Fig. 2 Compaction curves for Parit Nipah Peat

The maximum dry density ( $\gamma \mathrm{d}_{\max }$ of Laterite, Kaolin and Parit Nipah Peat is $1.630 \mathrm{Mg} / \mathrm{m}^{3}, 1.410$ $\mathrm{Mg} / \mathrm{m}^{3}, 0.490 \mathrm{Mg} / \mathrm{m}^{3}$ and the OMC is $22.5 \%, 27 \%, 132.47 \%$ respectively. The difference can be allocate by some extended from the differences in the grain size distribution. Soil compactability determined by soil texture, soil water, organic matter content, soil aggregation and compaction effort [5]. At a lower water contents, the soil is stiff and the soil grains offer more resistance to compaction. The dry density achieved depends upon the type of soil. A well graded soil attains a higher dry density that a poorly graded soil. The susceptibility to compaction increases as soil organic matter content decrease. Due to lower specific gravity and higher water holding capacity, dry unit weight of peat is lower than inorganic soils.

Unconfined Compressive Strength Test Unconfined compression strength (UCS) test were carried out on Laterite, Kaolin and Parit Nipah Peat .The results are shown in Fig. 3 and Table 3. Meanwhile Fig. 4 shows the failure patterns of the samples.

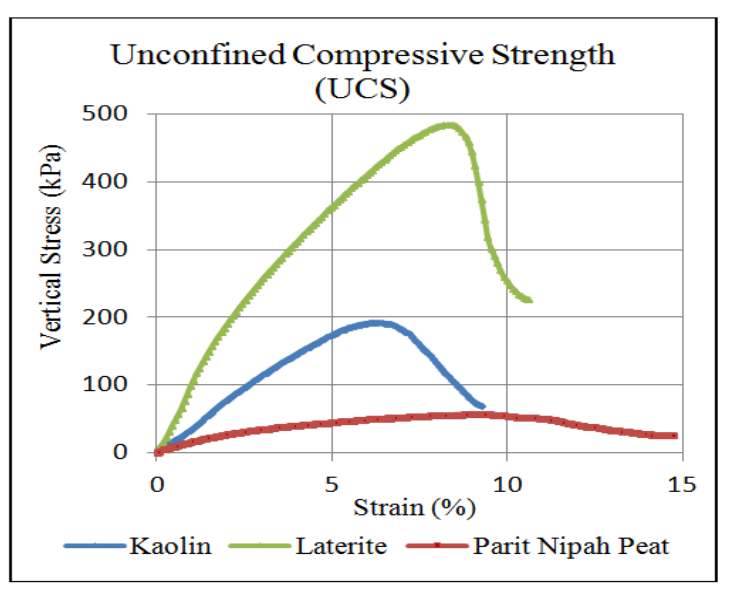

Fig. 3 Behaviour of UCS test on different types of soils
Table 3 : Summary of UCS test

\begin{tabular}{|c|c|c|c|}
\hline $\begin{array}{c}\text { Soil } \\
\text { types }\end{array}$ & $\begin{array}{c}\mathrm{UCS} \\
(\mathrm{kPa})\end{array}$ & $\begin{array}{c}\mathrm{Cu} \\
(\mathrm{kPa})\end{array}$ & $\begin{array}{c}\text { Moist. } \\
\text { Content(\%) }\end{array}$ \\
\hline Laterite & 484.03 & 242.02 & 15.95 \\
\hline Kaolin & 192.55 & 96.28 & 25.13 \\
\hline $\begin{array}{c}\text { P.N. } \\
\text { Peat }\end{array}$ & 56.91 & 28.45 & 135.74 \\
\hline \multicolumn{1}{|c}{} \\
\hline
\end{tabular}

(a)

(b)

(c)

Fig. 4 Failure patterns of UCS samples

(a) Kaolin (b) Laterite (c) Parit Nipah Peat

Table 3 shown that, Laterite has the highest Unconfined Compressive Strength (UCS) of 484.03 $\mathrm{kPa}$. While the UCS of Kaolin was $192 \mathrm{kPa}$ and Parit Nipah Peat (P.N. Peat) has the lowest UCS of $56.91 \mathrm{kPa}$. From the obtained result, it can be conclude that the main factor that causing to the difference result is water content, soil texture and bulk density. It was found that the lower water 
content, the greater the soil strength. Soils that have higher water content have weak soil strength. Since the samples was compacted, soil texture also affects soil strength, this is because soils with a broad distribution of particle size are considered the most compactable although fine textured soils have been found to compact to relatively high densities [6]. Soils with a broad distribution particle sizes resisted strength more than soil with fine material. Bulk density is the third factor affecting soil strength as bulk density of a given soil increases soil strength also increases

California Bearing Ratio (CBR) Tests The CBR test was carried out for both unsoaked and 4 days soaked samples, as required. For the unsoaked condition, CBR tests were carried out immediately. The relation of CBR value with respect to different soil properties are presented in Table 4.

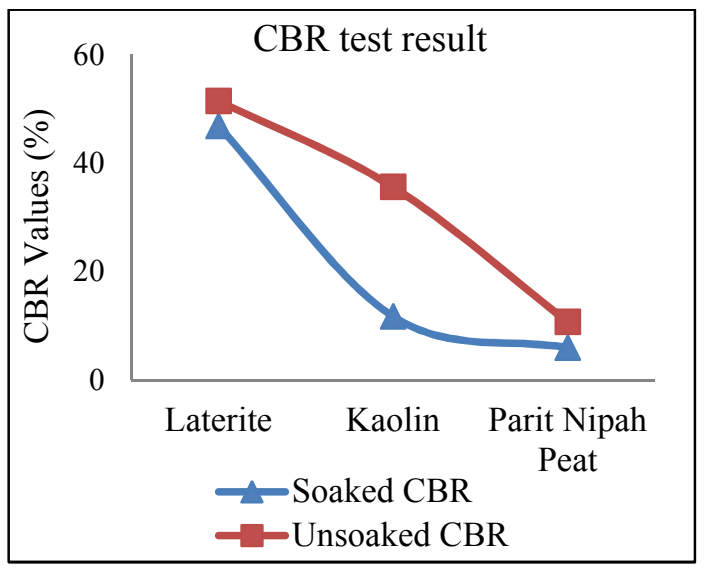

Table 4 Summary of CBR result

\begin{tabular}{|c|c|c|c|c|}
\hline \multirow{2}{*}{ Soils } & \multicolumn{2}{|c|}{ CBR Value } & \multicolumn{2}{c|}{ Swelling index } \\
\cline { 2 - 5 } & unsoaked & soaked & $\begin{array}{c}\text { Dif. } \\
\text { Swelling } \\
\text { (mm) }\end{array}$ & $\mathbf{( \% )}$ \\
\hline Laterite & 51.5 & 46.82 & 0.28 & 0.65 \\
\hline Kaolin & 35.6 & 11.75 & 3.2 & 7 \\
\hline $\begin{array}{c}\text { Parit } \\
\text { Nipah } \\
\text { Peat }\end{array}$ & 10.76 & 5.99 & 11.9 & 52.19 \\
\hline
\end{tabular}

Fig. 5 Soaked /unsoaked CBR values of different types of soil

Unsoaked CBR samples gives higher value compared to soak CBR for all types of soil. This is due to unsoaked soil specimen was partially saturated and having high suction pressure leads to high pressure between clay particles results high CBR value. It can be concluded that the CBR value of a given soil is controlled by the densification (the CBR value of the soil is dependent on the relative dry unit weight) [7]. The factors affecting CBR value are soil texture, moisture, and density. The testing procedure employed will depend on the type of material being tested. Granular soils were not greatly affected by swelling during the soaking period, and, therefore, the surcharge weights are not significant during this part of test [8]. In contrast, claylike soils, which are greatly affected by swelling pressures, will yield CBR values depending upon the weight of the surcharges used during the soaking period.

\section{Conclusion}

Analysis of data obtained from the study indicated that the geotechnical properties were influenced by different types of soil. This is because all the types of soil due to different water content, soil texture and bulk density. The behaviour and strength of soil is largely determined by the size of its particles and the migration of water through the soil skeleton. A change in water content influenced a change in the soil strength. Understanding the behaviour of various soils is an important concern to the engineer. A geotechnical property of soil is utmost important in designing from a buildings foundation to a highway overpass. So it is important for engineer to know how various soils behave in solving geotechnical problems. 


\section{Acknowledgements}

The authors would like to thank the University of Tun Hussein Onn, Malaysia, and the Ministry of Education, Malaysia, for their generous granted of this research, FRGS vot. 1061.

\section{References}

[1] A.V. Shroff and D.L. Shah: Soil Mechanics and Geotechnical Engineering., Introduction, Swets \& Zeitlinger,India (2003) p.1

[2] A.V. Shroff and D.L. Shah: Soil Mechanics and Geotechnical Engineering., Physical Properties of Soil, Swets \& Zeitlinger,India (2003) p.54

[3] B. Sen and S.K. Pal: Index properties of Soils collected from Different Locations and Correlations of Parameters., Electronic Journal of Geotechnical Engineering,vol.19, 2014-Bundle N (2014)

[4] B.M. Das: Principle of Foundation Engineering, SI Edition.,Geotechnical Properties of Soil.,seven ed.,Cengate Learning,United States of America (2010)

[5] K. Barik, M.Y. Canbolat, R. Yanik and K. Rafiq Islam: Compressive behaviour of soil as affected by aggregate size with different textures in Turkey. J. Animal Plant Sci (2011) p.186-192.

[6] K. Froese: Bulk density,soil strength, and soil disturbance impacts from a cut-to-length harvest operation in north central Idaho. M.Sc. thesis, Univ. Of Idaho (2004)

[7] S. Horpibulsuk, A. Suddeepong, P. Chamket, A. Chinkulkijniwat: Compaction behaviour of fine-grained soils, lateritic soils and crushed rocks., The Japanese Geotechnical Society (2012)

[8] E.J. Yoder and M.W. Witczak: Principle of Pavement Design.,Materials Characterization, John Wiley \& Sons, Canada (1975) p.253 